\title{
Evaluation of Olfactory Fossa Anatomy by Computed Tomography and the Place of Keros Classification in Functional Endoscopic Sinus Surgery
}

\author{
(1) Emrah Karatay, ${ }^{1}$ () Hakan $\mathrm{AvCl}^{2}$
}

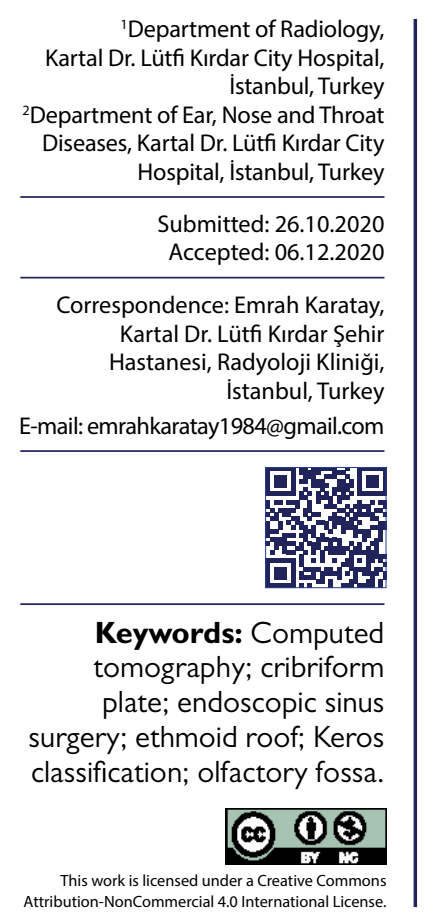

\begin{abstract}
Objective: Functional endoscopic sinus surgery (FESS) is a frequently used treatment method, and it is important to know the anatomy of the paranasal sinuses, olfactory fossa and adjacent anatomical structures during surgery. Paranasal sinus computed tomography (CT) is a frequently used imaging method in the evaluation of the paranasal sinuses, nasal cavity and nasopharynx. Our study aims to determine Keros types and their incidence by retrospectively evaluating the depth of the olfactory fossa in our population according to the Keros classification on paranasal sinus CT images.
\end{abstract}

Methods: In this study, the images of the patients who were directed by the otorhinolaryngology clinic and who underwent non-contrast paranasal sinus CT examination in the Radiology clinic between December 2018 and June 2019 were evaluated retrospectively. As a result, 522 patients between the ages of 18 and 87 were included in our study.

Results: The average depth of the total 1044 olfactory fossa (OF) examined was $4.89 \mathrm{~mm}$ with a standard deviation (SD) calculated of \pm 2.79 . Statistically, a significant difference was found between males and females in mean OF depth $(\mathrm{p}<0.00 \mathrm{I})$. According to Keros classification, 322 sides (30.85\%) had type I, 697 sides (66.75\%), type 2 and 25 sides (2.4\%) had type 3 in 1044 olfactory fossa. To our knowledge, this study has the largest case series for the olfactory fossa in our country, and the data were obtained in a tertiary health center.

Conclusion: The routine use of Keros classification for the left and right side in paranasal sinus $\mathrm{CT}$ reporting will help minimize surgical complications by providing valuable contributions to the surgical branches related to the anatomy of this region.

\section{INTRODUCTION}

Functional endoscopic sinus surgery (FESS) is a frequently used method, and it is important to know the anatomy of the paranasal sinuses, olfactory fossa and adjacent anatomical structures during surgery. Because the paranasal sinuses are adjacent to the orbital spaces and the brain, the surgeon should be aware of sinonasal anatomy and associated variations. ${ }^{[l-3]}$ Such an anatomical approach is one of the main factors that directly affect FESS results and complication rates. In some sources, the olfactory fossa (OF) and the area around the ethmoid cellular are called the 'dangerous zone. ${ }^{[3]}$ If the depth and anatomical variations of the olfactory fossa are not considered in preoperative imaging, complications may occur more frequently during surgery. ${ }^{[3,4]}$
Paranasal sinus computed tomography (CT) is a frequently used imaging method in the evaluation of the paranasal sinuses, nasal cavity and nasopharynx. Also, bone structures can be evaluated effectively due to the ability to obtain images in axial and coronal planes. ${ }^{[1-3]}$ Preoperative evaluation of the anatomy of the ethmoid roof, anterior cranial fossa and related bone structures adjacent to the olfactory fossa will provide a safer route during surgery and reduce postoperative complications. Therefore, paranasal sinus CT is very valuable before endoscopic sinus surgery. ${ }^{[3,4,5]}$ Ethmoidal foveal asymmetry, anatomical variations of the olfactory fossa (OF) and lateral lamella, as well as the course of the anterior ethmoid artery, are critical for endoscopic sinus surgery as they may cause iatrogenic damage. The asymmetry of the depth of both sides' olfactory fossa or the height of the ethmoidal roof may lead to a higher risk of intracranial 
penetration during endoscopic sinus surgery. ${ }^{[3,6]}$ The olfactory fossa is a depression in the anterior cranial cavity where it forms the base of the ethmoid cribriform plate. The lateral lamella of the cribriform plate is located in the lateral part of the olfactory fossa, and the crista galli is located in the medial part. The depth of the olfactory fossa is determined by the height of the lateral lamella of the cribriform plate (Fig. I).

According to the classification made by Keros in 1962, the depth of the olfactory fossa is evaluated in thre categories: type I, I-3 mm; type 2, 4-7 mm; and type 3, 8-16 mm (Fig. 2). ${ }^{[7]}$ Type 3 is the most dangerous and important type of endoscopic sinus surgery and has a very thin cribriform plate. ${ }^{[8]}$ After the Keros classification, several studies have been conducted on the ethmoid roof and OF based on Keros classification in various populations over the years. ${ }^{[8-12]}$ Contrary to the Keros types and classification, there is also the Yenigun classification based on the anterior ethmoidal artery and ethmoid roof and evaluating the olfactory fossa as transverse. ${ }^{[13]}$ According to this classifi-

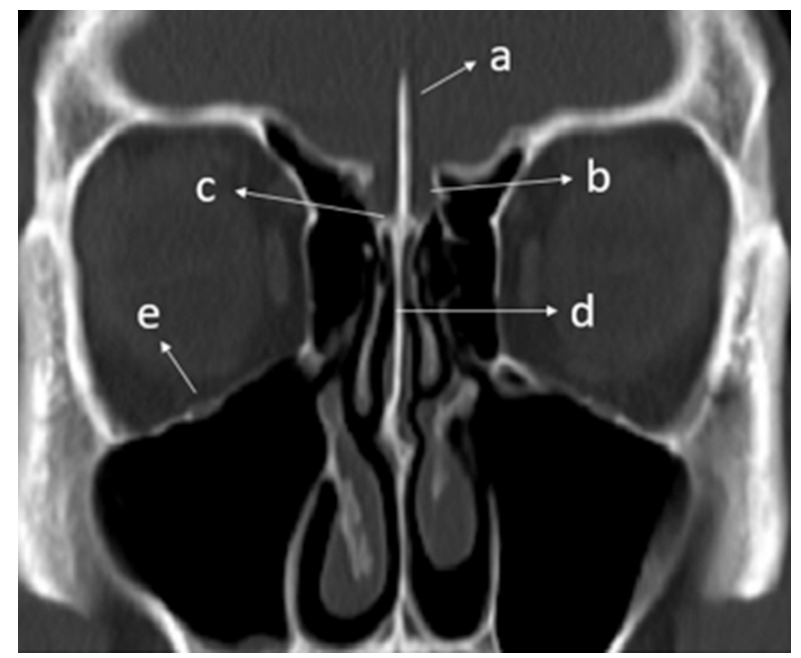

Figure 1. In paranasal sinus CT coronal plane images; a) crista galli b) olfactory fossa c) cribriform plate d) perpendicular plate and e) infraorbital nerve are seen. cation, as the length of the canal of the anterior ethmoidal artery and the incidence of the artery increases, the risk of injury increases.

Our study aims to determine Keros species and its incidence by retrospectively evaluating the depth of the olfactory fossa in our population according to the Keros classification on paranasal sinus CT images. We tried to evaluate the distribution of Keros types and various asymmetry parameters in paranasal sinus CT of as many patients as possible. Besides, olfactory fossa asymmetry and gender differences were evaluated.

\section{MATERIALS AND METHODS}

\section{Patient selection}

Ethical approval was obtained from the Institutional Review Board of the local ethics committee of our hospital (IRB:20I9/5I4/I54/I2). In this study, the images of the patients who were directed by the otolaryngology clinic and who underwent non-contrast paranasal sinus CT examination in the Radiology clinic between December 2018 and June 2019 were evaluated retrospectively. Patients with a congenital facial anomaly, sinonasal polyposis, tumor, nasal-paranasal trauma, infection involving bone destruction, surgical history and age less than 18 years were excluded from this study. As a result, 522 patients between the ages of 18 and 87 were included in our study. Informed consent forms were available for all patients before CT scans.

\section{CT imaging and measurements}

Images of all patients were obtained using a 40-slice CT scanner (Siemens, SOMATOM Sensation 40). CT parameters were $120 \mathrm{kV}, 300 \mathrm{mAs}$, rotation time I sec, section thickness $2 \mathrm{~mm}$, a field of view (FOV) $15 \mathrm{~mm}$. All CT images were reconstructed and analyzed using the software "picture archiving and communication system" (PACS) INFINITT: 3.0.I I.4 (BNII) program. Only coronal images were used during this study and measurements were obtained by working in the bone window. Paranasal sinus CT
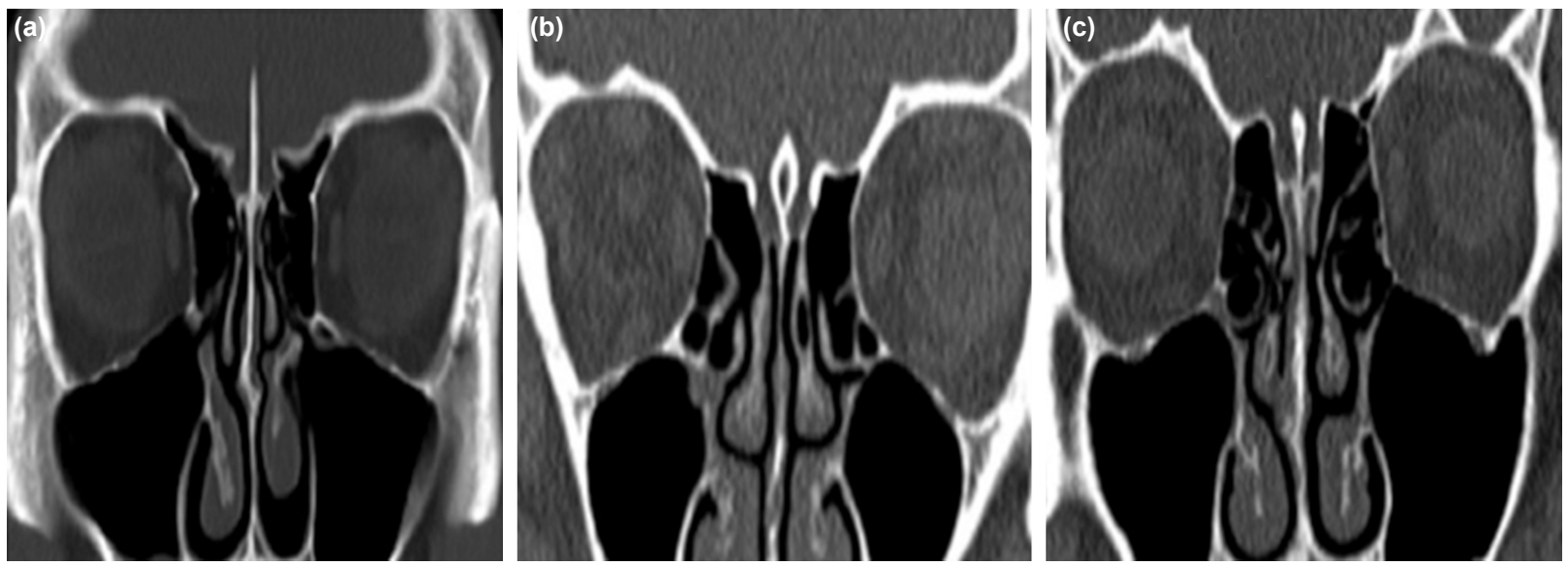

Figure 2. According to the Keros classification, CT images of three types of olfactory fossa in the coronal plane are shown respectively; (a) Keros type I (b) Keros type II (c) Keros type III. 
images for each patient were respectively evaluated by a radiologist experienced in head and neck radiology.

\section{Statistical analysis}

Statistical analysis of the data was performed using SPSS Statistics software (IBM SPSS ver 24.0, IBM, Armonk, NY, USA). Descriptive statistical methods (median, frequency, percent, minimum, and maximum) were used to express the central tendency. Kolmogorov-Smirnov test was used to evaluate the normality of quantitative data distribution. Pearson's chi-square test was used to compare categorical variables, and Fisher's exact test was applied if the number of subgroups was low. Mann-Whitney $U$ test was used to compare the differences between sexes and laterality. A p-value $<0.05$ was considered statistically significant.

\section{RESULTS}

In this study, 522 patients were included, 282 were males (54.02\%) and 240 were females (45.98\%). The average patient age was $37.46 \pm 13.45$ years in males, $39.01 \pm 14.85$ years in females and $38.17 \pm 14.12$ years in total. The youngest case in both sexes was 18-year-old, the oldest case in males was 78-year-old and 87 for females.
The average depth of the total 1044 olfactory fossa (OF) examined was $4.89 \mathrm{~mm}$ with a standard deviation (SD) calculated of 2.79. The average OF depth on the right side was $4.86 \mathrm{~mm}$, and the average depth on the left side was $4.91 \mathrm{~mm}$, respectively (Table I). Statistically, a significant difference was found between males and females in mean OF depth $(p<0.00 \mathrm{I})$. No statistically significant difference was found when the mean right OF depth was compared according to gender $(p>0.05)$. Similarly, when the mean depths of right and left OF were compared for all patients, no statistically significant difference was found $(p>0.05)$. However, when the mean left OF depth was compared by gender, there was statistical significance $(\mathrm{p}<0.00 \mathrm{I})$ (Table 2).

According to Keros classification in total 1044 olfactory fossa, type I was in 322 (30.85\%), type 2 in 697 (66.75\%) and type 3 in 25 (2.4\%) sides. Based on these data, type 2 is the most common on the right and left side and in both genders. In the total of the right-sided olfactory fossa; Keros type I 160 (30.7\%), type 2350 (67.0\%) and type $312(2.3 \%)$ subjects were present. In the left-side total; there were Keros type I 162 (31.0\%) subjects, type 2347 (66.5\%) and type 313 (2.5\%) subjects (Table 3$)$. When Keros types were compared between both genders and sides, no statistical significance was found ( $p>0.05$ ) (Table 4).

Table I. Distribution of olfactory fossa (OF) depth

\begin{tabular}{lccccc}
\hline & OF depth total & OF depth right & OF depth left & OF depth male & Of depth female \\
\hline Mean & 4.89 & 4.86 & 4.91 & 5.03 & 4.71 \\
$\mathrm{n}$ & 1044 & 522 & 522 & 564 & 480 \\
Standard deviation & 2.79 & 1.36 & 1.45 & 1.46 & 1.36 \\
\hline
\end{tabular}

Table 2. Difference in mean depth of olfactory fossa (OF) between genders

\begin{tabular}{llcccc}
\hline Gender & & $\mathbf{n}$ & Mean & Standard deviation & p-value \\
\hline Male & Right OF depth & 282 & 4.99 & 1.41 & $>0.05$ \\
Female & Right OF depth & 240 & 4.71 & 1.33 & $<0.001$ \\
Male & Left OF depth & 282 & 5.08 & 1.52 & $>0.05$ \\
Female & L eft OF depth & 240 & 4.71 & 1.39 & 1.36 \\
Total & Right OF depth & 522 & 4.86 & 1.45 & \\
& Left OF depth & 522 & 4.91 & & \\
\hline
\end{tabular}

Table 3. Distribution of olfactory fossa according to the side and Keros classification

\begin{tabular}{|c|c|c|c|c|c|c|}
\hline \multirow[t]{2}{*}{ Keros type } & \multicolumn{2}{|c|}{ Right } & \multicolumn{2}{|r|}{ Left } & \multicolumn{2}{|c|}{ Total } \\
\hline & $\mathbf{n}$ & Percentage (\%) & $\mathbf{n}$ & Percentage (\%) & $\mathbf{n}$ & Percentage (\%) \\
\hline Type I & 160 & 30.7 & 162 & 31.0 & 322 & 30.85 \\
\hline Type II & 350 & 67.0 & 347 & 66.5 & 697 & 66.75 \\
\hline Type III & 12 & 2.3 & 13 & 2.5 & 25 & 2.4 \\
\hline Total & 522 & 100 & 522 & 100 & 1044 & 100 \\
\hline
\end{tabular}


Table 4. Distribution of olfactory fossa based on Keros classification according to their sides and sex

\begin{tabular}{|c|c|c|c|c|c|c|c|}
\hline \multirow[t]{2}{*}{ Keros Type } & \multicolumn{2}{|c|}{ Right, n (\%) } & \multicolumn{2}{|c|}{ Left, n (\%) } & \multicolumn{3}{|c|}{ Total, n (\%) } \\
\hline & Male & Female & Male & Female & Male & Female & Overall \\
\hline Type I & $83(29.4)$ & 77 (32.1) & $82(29.1)$ & $80(33.3)$ & 165 (29.3) & 157 (32.8) & $322(30.85)$ \\
\hline Type II & $189(67.0)$ & 161 (67.I) & $190(67.4)$ & 157 (65.4) & 379 (67.2) & $318(66.2)$ & $697(66.75)$ \\
\hline Type III & $10(3.5)$ & $2(0.8)$ & $10(3.5)$ & $3(\mathrm{I} .3)$ & $20(3.5)$ & $5(1.0)$ & $25(2.4)$ \\
\hline Total & $282(100)$ & $240(100)$ & $282(100)$ & $240(100)$ & $564(100)$ & $480(100)$ & $1044(100)$ \\
\hline
\end{tabular}

Table 5. Literature review and our study

\begin{tabular}{lcccc}
\hline Studies & n & $\begin{array}{c}\text { Type I } \\
\text { (\%) }\end{array}$ & $\begin{array}{c}\text { Type 2 } \\
\text { (\%) }\end{array}$ & $\begin{array}{c}\text { Type 3 } \\
\text { (\%) }\end{array}$ \\
\hline Souza et al. ${ }^{[2]]}$ & 400 & 26.3 & 73.3 & 0.5 \\
Jang et al. ${ }^{[2]}$ & 205 & 30.5 & 69.5 & none \\
Anderhuber et al. ${ }^{[19]}$ & 272 & 14.2 & 70.6 & 15.2 \\
Nitinavakarn et al. ${ }^{[18]}$ & 88 & 11.9 & 68.8 & 19.3 \\
Adeel et al. ${ }^{[17]}$ & 77 & 29.9 & 49.4 & 20.8 \\
Basak et al. ${ }^{[20]}$ & 64 & 9 & 53 & 38 \\
Babu et al. ${ }^{[9]}$ & 1200 & 17.5 & 74.6 & 7.9 \\
Our study & 522 & 30.85 & 66.75 & 2.4 \\
\hline
\end{tabular}

There are few studies evaluating Keros types in the literature and our data are compared and summarized in Table 5.

In this study, the difference in the OF depth between the two sides by more than $\geq 0$. I mm was defined as asymmetry. Although asymmetry was observed in all 522 subjects examined, the difference between right and left side in 507 was $\leq 1 \mathrm{~mm}$ and 272 males and 235 females. However, in only 15 subjects, the difference was $>1 \mathrm{~mm}$, and there were 10 males and five females. In addition, there was no significant relationship between gender and symmetrical and asymmetrical OF distribution on both sides ( $p>0.05)$. Similarly, considering the distribution of the same and different Keros types on both sides by gender, only four males and three females had different Keros types on both sides, and there was no significant relationship ( $p>0.05)$.

\section{DISCUSSION}

With the development of multislice technology, thin-sectioned paranasal sinus CT not only reveals anatomical details in the best way but also provides important contributions to the diagnosis and treatment of paranasal sinus diseases. ${ }^{[14]}$ Given the relatively old spiral CT technology and the complexity of the cellular anatomy of the ethmoid, axial and coronal images optimally obtained in multislice technology provide useful data before FESS and during surgery. ${ }^{[15]}$ One of the oldest known studies on the olfactory fossa is the cadaver study published by Keros P. in 1962, and the classification described here has been used based on many articles published to date..$^{[7,16,17]}$
The most common type in our study was type II olfactory fossa $(66.75 \%)$, similar to many other studies. ${ }^{[18-20]}$ This was followed by type I and type 3 in the order of occurrence. Using the Keros classification, we obtained percentages that were relatively similar to the values in several previous studies. ${ }^{[21-23]}$ A statistically significant difference was found between males and females in mean OF depth, similar to some previous studies. ${ }^{[6,9]}$ Also, we did not find a significant difference in mean OF depth between the right and left sides. In Babu et al. study, a statistically significant relationship was found between Keros type and gender, especially on the right side. ${ }^{[9]}$

Although the rate of asymmetry in our study group was quite high (97.1\%) compared to other studies, asymmetry was $>1 \mathrm{~mm}$ in only $2.9 \%$ of cases. Finally, only seven subjects (I.3\%) had different Keros type OFs on both sides, which was higher in Babu et al. and Pawar et al. ${ }^{[9,24]}$ In the study conducted by Babu et al., the mean OF depth was $5.26 \pm 1.69 \mathrm{~mm}$, which was slightly higher than in our study. Similarly, although there was a statistically significant difference in mean OF depth between males and females, no difference was observed between the right and left sides. Again, this study has one of the largest case series in the literature. ${ }^{[9]}$ Souza et al. used the coronal plan on CT images in their study; the most common type 2 olfactory fossa $\mathbf{7 3 3 . 3 \% )}$ was observed with the Keros classification in their cases, and similar to our study, they found the least type 3 olfactory fossa $(0.5 \%)$. Also, a remarkable asymmetry has been achieved in the ethmoid roof height and contour. ${ }^{[21]}$ In the study of Salroo et al. a statistically significant difference between the depths of the right and left lateral olfactory fossa was found, and when they compared the relationship between Keros classification and gender, there was a similar difference. In the same study, it is stated that the preoperative evaluation of ethmoid roof anatomy is essential. ${ }^{[5]}$

In a few studies, Keros type I is most common, followed by type II and III, respectively. ${ }^{[25-28]}$ Unlike other studies, Costa et al., in the images of the paranasal sinus, they obtained using cone-beam computed tomography; according to the Keros classification, the most common type 2 olfactory fossa and the least type I olfactory fossa were observed. There was also no significant difference between sex and age and the depths of the right and left-sided olfactory fossa. ${ }^{[2]}$

Yenigun et al. ${ }^{[13]}$ developed a new classification in addition to the Keros classification for the ethmoid roof based on 
visualization of the anterior ethmoidal artery, analyzing its relationship with neighboring structures in coronal, axial and sagittal CT images, evaluating its relationship with the ethmoid roof. The Keros classification used to measure lateral depth has been modified to measure the anteroposterior length of the cribriform plate on the ethmoid roof. It has been shown that in the presence of supraorbital pneumatization, the anterior ethmoidal artery observability increases bilaterally. Besides, it has been shown that the increased depth and length of the lateral lamella of the cribriform plate increases the visualization of the anterior ethmoidal artery and thus the risk of injury. ${ }^{[13]}$ On the other hand, Alberto et al., using the Keros and Yenigun classifications together, did not find a significant difference between gender and Keros types in their study. According to the Yenigun classification, type I was more common, and there was a statistically significant difference between males and females in types I and II. ${ }^{[I]}$

In this study, we aimed to evaluate the distribution of Keros types and various asymmetry parameters in paranasal sinus CT of as many patients as possible. Secondary to this, we obtained one of the largest series in the literature with 522 patients. ${ }^{[9,30,31]}$ Also, to our knowledge, our study has the largest case series for the olfactory fossa in our country, and the data were obtained in a tertiary health center. Finally, during our study, it is an important advantage that the data can be measured via PACS, which is easily accessible and easy to use.

In this study, taking measurements by a single radiologist can be considered a limitation. Besides, the fact that we cannot obtain additional information about the ethmoid roof using the Yenigun classification can be listed as another limitation. Another limitation can be considered as not using special software during paranasal sinus CT measurements. Although our case number is sufficient, we believe that new studies with metanalysis and a higher number of cases will contribute positively to the Keros classification in routine $\mathrm{CT}$ reporting.

\section{CONCLUSION}

Keros classification is very important in an objective evaluation of the anterior skull base anatomy and helps the surgeon's approach to a safe procedure during surgery, especially FESS. Thus, the surgical approach can be carefully planned and possible complications during surgery can be prevented. The routine use of Keros classification for the left and right side in paranasal sinus CT reporting will help minimize surgical complications by providing valuable contributions to the surgical branches related to the anatomy of this region.

Ethics Committee Approval

Approval Ethical approval was obtained from the Institutional Review Board of the local ethics committee of our hospital (IRB:2019/5/4/I54/I2).

\section{Peer-review}

Internally peer-reviewed.

Authorship Contributions

Concept: E.K.; Design: E.K., H.A.; Supervision: E.K.; Materials: E.K., H.A.; Data: E.K., H.A.; Analysis: E.K.; Literature search: E.K., H.A.; Writing: E.K.; Critical revision: E.K., H.A.

Conflict of Interest

None declared.

\section{REFERENCES}

1. Zinreich SJ. Paranasal sinus imaging. Otolaryngol Head Neck Surg 1990;103:863-9. [CrossRef]

2. Som PM, Lawson W, Fatterpekar GM, Zinreich J. Embryology, anatomy, physiology and imaging of the sinonasal cavities. In: Som PM, Curtin HD, editors. Head and neck imaging. 5th ed. St. Louis: Elsevier; 2011.p. 119-28. [CrossRef]

3. Erdem G, Erdem T, Miman MC, Ozturan O. A radiological anatomic study of the cribriform plate compared with constant structures. Rhinology 2004;42:225-9.

4. Cashman EC, Macmahon PJ, Smyth D. Computed tomography scans of paranasal sinuses before functional endoscopic sinus surgery. World J Radiol 2011;3:199-204. [CrossRef]

5. Salroo IN, Dar NH, Yousuf A, Lone KS. Computerised tomographic profile of ethmoid roof on basis of Keros classification among ethnic Kashmiri's. Int J Otorhinolaryngol Head Neck Surg 2016;2:1-5.

6. McMains KC. Safety in endoscopic sinus surgery. Curr Opin Otolaryngol Head Neck Surg 2008;16:247-51. [CrossRef]

7. Keros P. On the practical value of differences in the level of the lamina cribrosa of the ethmoid. Z Laryngol Rhinol Otol 1962;41:809-13.

8. Jacob TG, Kaul JM. Morphology of the olfactory fossa - A new look. J Anatomic Soc India 2014;63:30-5. [CrossRef]

9. Babu AC, Nair MRPB, Kuriakose AM. Olfactory fossa depth: CT analysis of 1200 patients. Indian J Radiol Imaging 2018;28:395. [CrossRef]

10. Erdogan S, Keskin IG, Topdag M, Ozturk M, Sari F, Mutlu F. Ethmoid roof radiology; analysis of lateral lamella of cribriform plate. Otolaryngol Pol 2015;69:53-7. [CrossRef]

11. Muñoz-Leija MA, Yamamoto-Ramos M, Barrera-Flores FJ, TreviñoGonzález JL, Quiroga-Garza A, Méndez-Sáenz MA, et al. Anatomical variations of the ethmoidal roof: differences between men and women. Eur Arch Otorhinolaryngol 2018;275:1831-6. [CrossRef]

12. V AM, Santosh B. A study of clinical significance of the depth of olfactory fossa in patients undergoing endoscopic sinus surgery. Indian J Otolaryngol Head Neck Surg 2017;69:514-22. [CrossRef]

13. Yenigun A, Goktas SS, Dogan R, Eren SB, Ozturan O. A study of the anterior ethmoidal artery and a new classification of the ethmoid roof (Yenigun classification). Eur Arch Otorhinolaryngol 2016;273:3759-64. [CrossRef]

14. Kayalioglu G, Oyar O, Govsa F. Nasal cavity and paranasal sinus bony variations: a computed tomographic study. Rhinology 2000;38:10813.

15. Zinreich SJ, Kennedy DW, Rosenbaum AE, Gayler BW, Kumar AJ, Stammberger H. Paranasal sinuses: CT imaging requirements for endoscopic surgery. Radiology 1987;163:769-75. [CrossRef]

16. Skorek A, Tretiakow D, Szmuda T, Przewozny T. Is the Keros classification alone enough to identify patients with the dangerous ethmoid'? An anatomical study. Acta Otolaryngol 2017;137:196-201.

17. Adeel M, Ikram M, Rajput MS, Arain A, Khattak YJ. Asymmetry of lateral lamella of the cribriform plate: a software-based analysis of 
coronal computed tomography and its clinical relevance in endoscopic sinus surgery. Surg Radiol Anat 2013;35:843-7. [CrossRef]

18. Nitinavakarn B, Thanaviratananich S, Sangsilp N. Anatomical variations of the lateral nasal wall and paranasal sinuses: a CT study for endoscopic sinus surgery (ESS) in Thai patients. J Med Assoc Thai 2005;88:763-8.

19. Anderhuber W, Walch C, Fock C. Configuration of ethmoid roof in children 0-14 years of age. Laryngorhinootologie 2001;80:509-11.

20. Basak S, Akdilli A, Karaman CZ, Kunt T. Assessment of some important anatomical variations and dangerous areas of the paranasal sinuses by computed tomography in children. Int J Pediatr Otorhinolaryngol 2000;55:81-9. [CrossRef]

21. Souza SA, de Souza MMA, Idagawa M, Wolosker AMB, Ajzen SA. Computed tomography assessment of the ethmoid roof: a relevant region at risk in endoscopic sinus surgery. Radiol Bras 2008;41:143-7.

22. Jang YJ, Park HM, Kim HG. The radiographic incidence of bony defects in the lateral lamella of the cribriform plate. Clin Otolaryngol Allied Sci 1999;24:440-2. [CrossRef]

23. Güler C, Uysal IÖ, Polat K, Salk I, Müderris T, Koşar MI. Analysis of ethmoid roof and skull base with coronal section paranasal sinus computed tomography. J Craniofac Surg 2012;23:1460-4. [CrossRef]

24. Pawar A, Konde S, Bhole P. Assessment of depth of olfactory fossa in pre-functional endoscopic sinus surgery computed tomography scan of paranasal sinuses. Int J Otorhinolaryngol Head Neck Surg 2017;4:83-6. [CrossRef]
25. Alazzawi S, Omar R, Rahmat K, Alli K. Radiological analysis of the ethmoid roof in the Malaysian population. Auris Nasus Larynx 2012;39:393-6. [CrossRef]

26. Solares CA, Lee WT, Batra PS, Citardi MJ. Lateral lamella of the cribriform plate: software-enabled computed tomographic analysis and its clinical relevance in skull base surgery. Arch Otolaryngol Head Neck Surg 2008;134:285-9. [CrossRef]

27. Nouraei SA, Elisay AR, Dimarco A, Abdi R, Majidi H, Madani $\mathrm{SA}$, et al. Variations in paranasal sinus anatomy: implications for the pathophysiology of chronic rhinosinusitis and safety of endoscopic sinus surgery. J Otolaryngol Head Neck Surg 2009;38:32-7.

28. Paber JE, Salvador M, Villarta R. Radiographic analysis of the ethmoid roof based on Keros classification among Filipinos. Philipp J Otolaryngol Head Neck Surg 2008;23:15-9. [CrossRef]

29. Costa ALF, Paixão AK, Gonçalves BC, Ogawa CM, Martinelli T, Maeda FA, et al. cone beam computed tomography-based anatomical assessment of the olfactory fossa. Int J Dent 2019;2019:4134260. [CrossRef]

30. Kaplanoglu H, Kaplanoglu V, Dilli A, Toprak U, Hekimoğlu B. An analysis of the anatomic variations of the paranasal sinuses and ethmoid roof using computed tomography. Eurasian J Med 2013;45:115-25. [CrossRef]

31. Poje G, Mladina R, Skitarelic N, Marjanovic Kavanagh M. Some radiological and clinical aspects of the sinus crista galli. Roman J Rhinol 2014;13:31-6.

\section{Olfaktör Fossa Anatomisinin Bilgisayarlı Tomografi Ile Değerlendirilmesi ve Keros Sınıflandırmasının Fonksiyonel Endoskopik Sinüs Cerrahisindeki Yeri}

Amaç: Fonksiyonel endoskopik sinüs cerrahisi (FESS) sık kullanılan bir tedavi yöntemidir ve ameliyat sırasında paranazal sinüslerin, olfaktör fossa ve komşu anatomik yapıların anatomisinin bilinmesi önemlidir. Paranazal sinüs bilgisayarlı tomografi (BT), paranazal sinüslerin, nazal kavite ve nazofarenksin değerlendirilmesinde sıklıkla kullanılan bir görüntüleme yöntemidir. Bu çalısmamız, paranazal sinüs BT görüntülerinde Keros sınıflamasına göre popülasyonumuzdaki olfaktör fossa derinliğini geriye dönük olarak değerlendirerek Keros tiplerini ve görülme sıklı̆ı̆ı belirlemeyi amaçlamaktadır.

Gereç ve Yöntem: Bu çalışmada, Aralık 2018-Haziran 2019 tarihleri arasında kulak burun boğaz kliniği tarafından yönlendirilen ve Radyoloji kliniğinde kontrastsız paranazal sinüs BT incelemesi yapılan hastaların görüntüleri geriye dönük olarak değerlendirildi. Sonuç olarak I8-87 yaşları arasında 522 hasta çalışmamıza dahil edildi.

Bulgular: İncelenen toplam 1044 koku fossasının (OF) ortalama derinliği 4,89 mm ve standart sapma (SD) \pm 2.79 olarak hesaplandı. Ortalama OF derinliği açısından erkekler ve kadınlar arasında istatistiksel olarak anlamlı fark bulundu $(p<0.00$ I). Toplam 1044 olfaktör fossada Keros sınıflandırmasına göre, 322 tarafta (\%30.85) tip I, 697 tarafta (\%66.75) tip 2 ve 25 tarafta (\%2.4) ise tip 3 mevcuttu. Bu çalısma, ülkemizdeki en büyük olfaktör fossa olgu çalışmasına sahiptir ve verileri üçüncü basamak bir sağlık merkezinde elde edilmiştir.

Sonuç: Paranazal sinüs BT raporlamasında sol ve sağ taraf için Keros sınıflandırmasının rutin olarak yapılması, bu bölgenin anatomisi ile ilgili cerrahi branşlara değerli katkılar sağlayarak, cerrahi komplikasyonları en aza indirmeye yardımcı olacaktır.

Anahtar Sözcükler: Bilgisayarlı tomografi; cribriform plate; endoskopik sinüs cerrahisi; ethmoid roof; Keros sınıflandırması; olfaktör fossa. 